\title{
MODEL PEMBELAJARAN KETERAMPILAN PASSING FUTSAL BERBASIS PERMAINAN UNTUK SMA
}

\author{
Chairul Umam Ramadhan ${ }^{1}$, Widiastuti ${ }^{2}$, Samsudin ${ }^{3}$ \\ 1,2,3 Pendidikan Jasmani Pascasarjana, Universitas Negeri Jakarta, \\ Jalan Rawamangun Muka, Rawamangun, Pulo Gadung, \\ Kota Jakarta Timur, Indonesia \\ 1e-mail: chairulumamr@yahoo.co.id
}

\begin{abstract}
Abstrak
Tujuan dari penelitian ini adalah untuk menghasilkan produk model pembelajaran keterampilan passing futsal berbasis permainan untuk Sekolah Menegah Atas. Penelitian ini dilakukan untuk dapat memperoleh informasi tentang pengembangan dan penerapan pembelajaran keterampilan passing futsal berbasis permainan untuk sekolah menegah atas serta untuk mengetahui efektivitas model yang dihasilkan. Penelitian ini menggunakan metode Research \& Development (R\&D) dari Borg and Gall. Subyek dalam penelitian ini adalah siswa SMA yang mengikuti ekstrakulikuler futsal yang terdiri dari 20 siswa untuk uji kelompok kecil, 60 siswa untuk uji kelompok besar dan 39 siswa untuk uji efektifitas. Tahapan-tahapan dalam penelitian ini adalah: analisis kebutuhan, evaluasi ahli (evaluasi produkawal), uji coba kelompok kecil, dan uji coba kelompok besar (field testing). Uji efektivitas model menggunakan tes keterampilan passing futsal yang digunakanuntukmengetahuitingkatkemampuanpassing futsal siswa sebelum dan sesudah pemberian perlakuan model pembelajaran keterampilan passing futsal yang dikembangkan. Tes awal yang dilakukan diperoleh tingkat kemampuan passing siswa adalah 8.394. Setelah diberikan perlakuan model pembelajar keterampilan passing didapatkan tingkatk emampuan passing siswa10.657. Pada uji signifikan didapatkan mean $=-2.26316$ menunjukan selisih dari hasil pre-test dan hasil post-test, hasil t-hitung $=-11.014 \mathrm{df}=37 \mathrm{dan} \mathrm{p}$-value $=0.00<0.05$ yang berarti terdapat perbedaan yang signifikan antara sebelum dan sesudah diberikan perlakuan model pembelajaran keterampilan passing futsal.
\end{abstract}

Kata Kunci :Siswa SMA, futsal, Pembelajaran passing futsal

\begin{abstract}
The purpose of this research is to produce a model of learning a skill-based game futsal passing for high school. This research was conducted to obtain information on the development and application of learning a skill-based game to futsal passing school upper secondary as well as to find out the effectiveness of the resulting model. This research method using Research \& Development $(R \& D)$ of Borg and Gall. The subjects in this study were high school students who follow the extracurricular futsal consisting of 20 students to test small groups, 60 students to test large groups and 39 students to test effectiveness. Stages in this study are: needs analysis, evaluation experts (evaluation of early product), the free trial of small groups, and large group test (field testing). Test the effectiveness of the model using a futsal passing skills test used to find out the level of ability of the passing futsal students before and after administering the treatment model of learning the skill of passing futsal developed. Initial tests conducted acquired ability level of students ' passing was 8,394. After being given the treatment models of learners the skills obtained by passing ability level of the students passing 10,657. In a significant test of the obtained mean $=2.26316$-shows the difference between the results of pre-test and the results of the test, the results of
\end{abstract}


the post-t-count $=d f=11,014-37$ and p-value $=0.000 .05$ means that $<$ significant difference between before and after the given treatment learning the skill of passing futsal.

Keywords: High school students, futsal, passing futsal learning

\section{PENDAHULUAN}

Olahraga mendapat tempat dalam dunia kesehatan sebagai salah satu faktor penting dalam usaha pencegahan penyakit. Olahraga merupakan suatu kegiatan fisik yang pada dasarnya mengandung sifat permainan dan bersifat berjuang melawan diri sendiri dengan orang lain atau berbaur dengan alam. Kegiatan olahraga dewasa ini sudah menjadi bagian yang sangat dibutuhkan, karena olahraga sangat berpengaruh terhadap aktifitas gerak seseorang. Kegiatan olahraga tidak hanya memiliki makna sebagai sarana untuk kesehatan jasmani saja, tetapi olahraga dapat digunakan sebagai sarana pendidikan, prestasi dan olahraga sebagai alat pemersatu.

Fakta di lapangan terlihat mata pelajaran olahraga di sekolah terbatas oleh waktu, kesempatan dan fasilitas lingkungan. Begitu pula di lingkungan rumah, peserta didik terbatas dalam ruang gerak, sehingga kebutuhan peserta didik akan gerak tidak bisa terpenuhi. Peserta didik yang seharusnya dapat mengembangkan kemampuan fisik hingga optimal, penting untuk melibatkan diri dan mengikuti secara aktif di ekstrakulikuler sekolah. Salah satu ekstrakulikuler yang dapat diikuti untuk menyalurkan gerak aktivitas fisiknya ialah ekstrakulikuler futsal.

Berkembangnya cabang olahraga futsal di Sukabumi terlihat pesat dari banyaknya turnamen futsal yang telah diselenggarakan. Bahkan para eksekutif atau perusahaan besar pun seringkali menyelenggarakan turnamen futsal. Perkembangan futsal di Sukabumi tidak lepas dari perkembangan olahraga ini dari kalangan mahasiswa dan pelajar yang sangat pesat. Dengan adanya kejuaraankejuaraan pelajar inilah banyak bermunculan pemain futsal berbakat. Salah satu turnamen yang berkualitas yang sering di adakan di Sukabumi seperti pelajar Futsal League (turnamen antar sekolah ).

Namun ada beberapa perwakilan sekolah yang sering mengalami kekalahan, salah satunya perwakilan sekolah dari Kota Sukabumi. Tim perwakilan 
dari daerah ini hanya mampu lolos di fasegrup. Setelah saya mengamati, memang banyak pemain dari tim ini yang belum mahir dan memahami dasar dari permainan futsal, terlihat dari pemain tersebut belum akurat dalam melakukan passing. Maka dari itu saya melakukan observasi kepada pelatih tim tersebut. Hasilnya ternyata pelatih tersebut masih membutuhkan referensi tentang model pembelajaran passing yang lebih bervariasi. Karena para pemain merasa bosan dan tidak berkembang sehingga mempengaruhi penampilan saat permainan.

Berdasarkan latar belakang di atas, penulis tertarik membuat model pembelajaran keterampilan passing futsal berbasis permainan untuk SMA (Sekolah Menengah Atas). Sehingga dalam situasi permainan semua pemain dapat melakukan dan mengeluarkan semua kemampuan bermain dengan passing yang akurat.

Berdasarkan pemaparan latar belakang masalah dan fokus penelitian dapat dirumuskan masalah yaitu, (1) bagaimanakah model pembelajaran keterampilan passing futsal pada ekstrakurikuler SMA (Sekolah Menengah Atas)?; dan (2) Apakah model pembelajaran keterampilan passing futsal dapat meningkatkan keterampilan passing?.

Pada penelitian model pembelajaran keterampilan passing futsal berbasis permainan untuk siswa sekolah menegah atas memiliki dua tujuan, diantaranya yaitu: (1) mengembangkan suatu rancangan model pembelajaran keterampilan passing cabang olahraga futsal untuk siswa sekolah menegah atas; dan (2) memperoleh data serta fakta empiris tentang efektivitas hasil pengembangan model pembelajaran keterampilan passing futsal berbasis permainan untuk siswa sekolah menegah atas.

Hasil dari penelitian ini adalah untuk menghasilkan produk buku model pembelajaran keterampilan passing cabang olahraga futsal untuk pendidik sebagai pedoman serta rujukan dalam memberikan materi pembelajaran passing futsal yang lebih efektif dan variatif. Passing dalam cabang olahraga futsal merupakan hal yang paling utama seperti yang sudah dibahas di atas. Karena, merupakan kunci kesuksesan tim untuk selalu mengendalikan setiap permainan. Dalambukunya Vic Hermans dan Rainer Engler menjelaskan: 
"Passing is a technique and is therefore very often practiced in every training session. For correct passing (not only technically but also at the right time and to the right player), the movements of the teammates are equally as important as those of the ball carrier."

Dari penjelasan tersebut dapat dikatakan bahwa passing merupakan bagian dari teknik yang harus selalu dilatih disetiap sesi latihan untuk memperoleh gerakan yang baik dan benar, bukan hanya tentang gerakan tetapi juga ketepatan arah passing tersebut. Banyaknya kesalahan yang dilakukan saat passing sangat merugikan tim dan akan selalu menjadi hambatan untuk membangun setiap serangan kelawan.

Dengan banyaknya kesalahan yang terjadi dalam passing, untuk mencegah hal tersebut ada beberapa tahapan dalam pelaksanaan passing yang harus dipelajari, yaitu a) Sikap awalan, b) Sikap perkenaan bola, c) Sikap akhir.

Setiap pemain yang akan melakukan passing harus melakukan sikap awalan yang dapat menunjang gerakan serta tendangan atau passing tesebut dapat dilakukan dengan baik sehingga dapat terarah pada sasaran atau teman satu tim. Hal yang harus dilakukan yaitu sebagai berikut: (1) mengaturposisitubuh; (2) mencondongkan badan sedikit ke depan; (3) posisi kaki sudah ancang-ancang mengayunkan kaki ke belakang. Adapun contoh gambar dari gerakan tersebut disajikan pada gambar 1 (Andri, 2009).

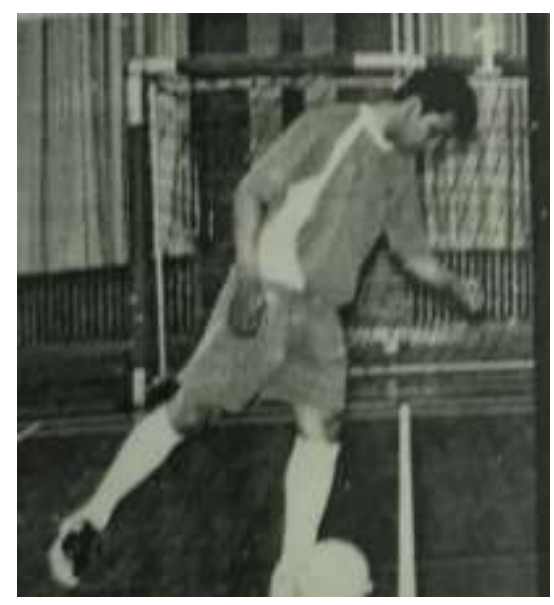

Gambar 1 Sikap Awalan Passing Futsal 
Dalam posisi ini seorang pemain futsal harus melakukan gerakan sebagai berikut: (1) pada saat perkenaan bola, penerima harus dalam keadaan siap dengan badan sedikit condong ke depan; (2) pastikan kaki yang terkena bola adalah tepat kaki bagian dalam; (3) sambil memperhatikan bola dahulu, lalu ayunkan kaki ke arah depan atau ke arah rekan. Adapun contoh gambar dari gerakan tersebut disajikan pada gambar 2 (Andri, 2009).

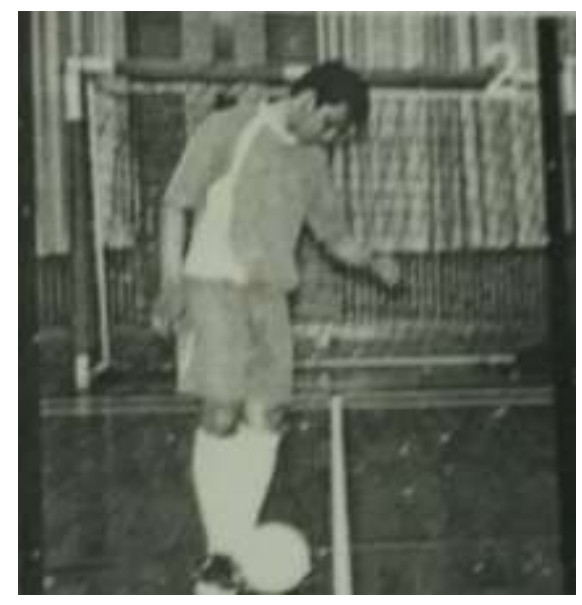

\section{Gambar 2 Sikap Perkenaan Bola}

Pada sikap akhir saat bola sudah lepas dari kaki upayakan posisi kaki mengikuti arah bola hingga tiba disasaran seperti gambar 3 (Andri, 2009).

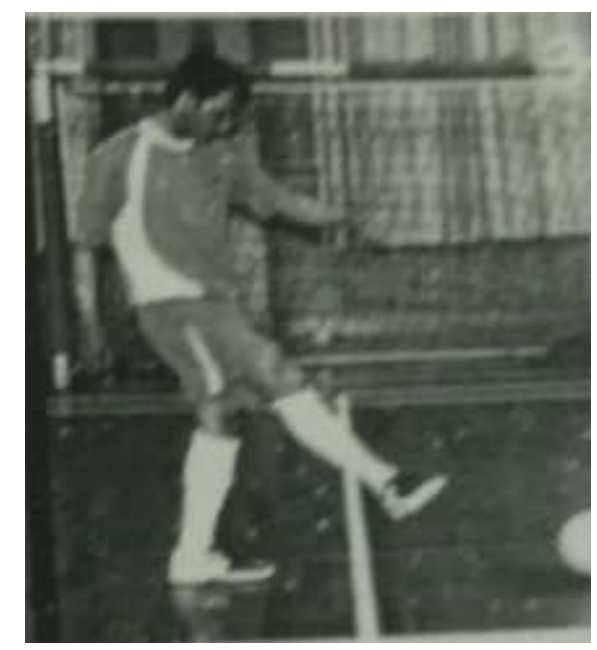

Gambar 3 Sikap Akhir 
Dari penjelasan dan gambar di atas dapat disimpulkan bahwa hal-hal tersebut harus selalu dilakukan oleh pemain yang akan melakukan passing agar gerakannya dapat terlaksana dengan baik serta tepat pada sasaran atau rekan.

\section{METODE}

Pendekataan dan metode penelitian pada Penelitian model pembelajaran keterampilan passing pada cabangolahraga futsal menggunakan penelitian dan pengembangan (Reaserch and Development) dari Borg dan Gall. Penelitian dan pengembangan ini terdiri dari sepuluh langkah, diantaranya yaitu:

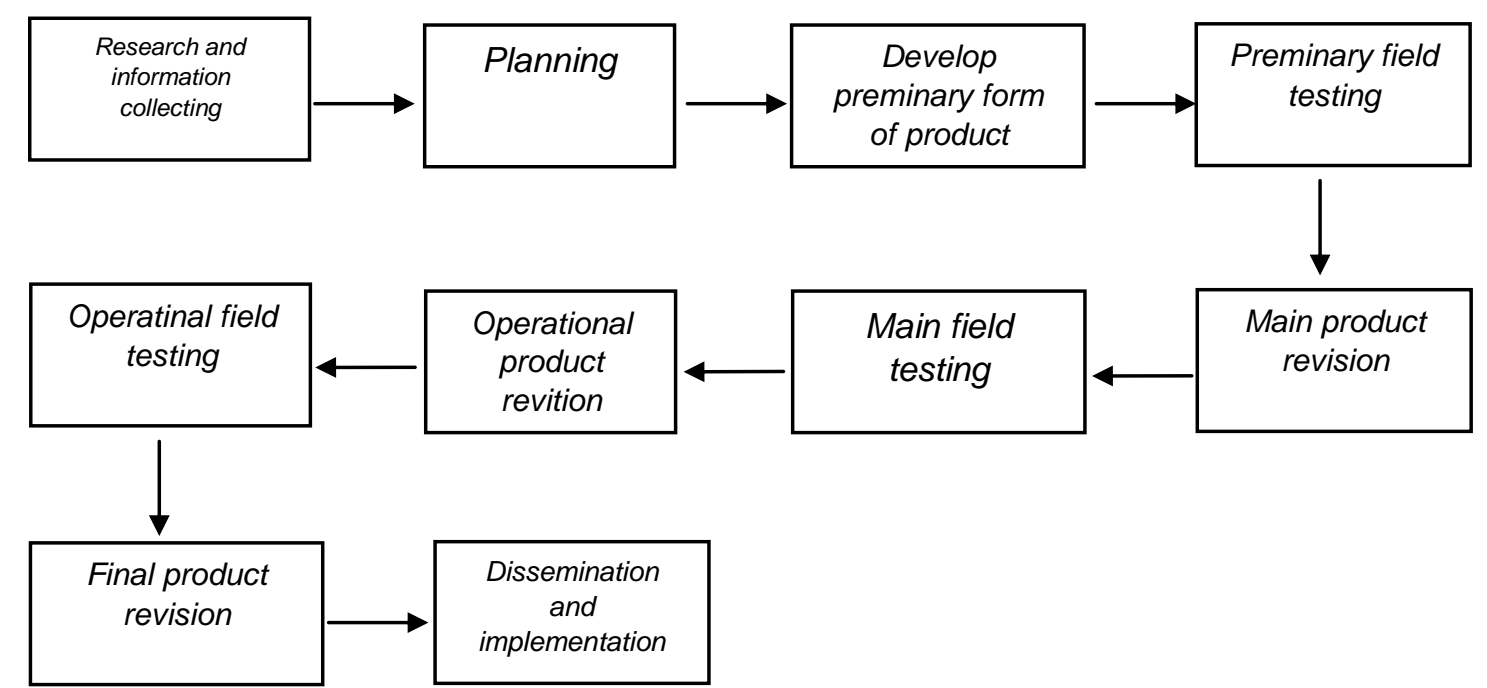

\section{Gambar 4 Chart Langkah-langkah Pengembangan Adaptasi dari Borg dan Gall, M.D (1983)}

Penelitian ini dilaksanakan di SMK Pasim Kota Sukabumi (uji kelompok kecil), SMAN 2 Kota Sukabumi (uji kelompok besar) dan SMAN 1 Parungkuda (uji efektifitas). Waktu penelitian dilaksanakan 5-26 November 2018. Dalam pelaksanaan model pembelajaran passing futsal untuk siswa SMA subjek melakukan 30 model pembelajaran passing futsal yang sudah peneliti siapkan. Model ini bertujuan untuk meningkatkan kemampuan passing futsal dan siswa mampu melakukan passing dengan baik.

Instrumen yang digunakan dalam penelitian ini berupa tes passing yang sudah divalidasi oleh ahli yang berjumlah 3 orang yaitu 1 orang dosen, 1 guru penjas, dan 1 pelatih futsal. Validasi ahli dilakukan untuk melihat apakah model 
yang peneliti buat layak atau tidak dan hasil dari validasi ahli dari 30 model yang peneliti buat hanya 22 yang layak untuk diterapkan dalam model pembelajaran passing futsal untuk siswa SMA, dilanjutkan validasi instrument passing futsal untuk kelas eksperimen, setelah validasi ahli selesai selanjutnya yaitu uji kelompok kecil yang berjumlah 30 orang di sekolah SMK Pasim, peneliti memberikan kuesioner penguatan untuk mengetahui apakah model yang diberikan dapat diterima oleh siswa dan hasilnya yaitu model yang berjumlah 22 dapat diterima oleh siswa.

Sebelum ketahap selanjutnya yaitu uji kelompok besar, peneliti merevisi kembali pelaksanaan model pembelajaran passing futsal untuk siswa SMA yang bertujuan untuk menyempurnakan model pembelajaran yang akan di uji cobakan kepada kelompok besar setelah merevisi selesai dapat dilanjutkan uji kelompok besar yang berjumalah 60 subjek uji coba ini dilakukan di SMAN 2 Kota Sukabumi, seperti uji kelompok kecil setelah melakukan uji coba model pembelajaran subjek diberi kuesioner penguatan yang bertujuan untuk melihat hasil dari model, dan hasilnya dapat diterima oleh siswa.

Selanjutnya, Setelah melakukan uji coba kelompok kecil dan besar dilanjutkan ke uji efektivitas produk model dengan cara one group pretest-posttest design menggunakan paired sample t test.

\section{HASIL DAN PEMBAHASAN}

Hasil tes yang diperoleh sebelum dan setelah diberikan perlakuan dapat disimpulkan bahwa model pembelajaran passing futsal berbasis permainan untuk SMA layak dan efektif untuk dapat meningkatkan kemampuan passing. Dalam uji signifikan yang dilakukan dengan menggunakan SPSS 16 didapat mean= -2.263 menunjukan selisih dari hasil pre-test dan hasil post-test kelompok eksperimen, hasil t-hitung $=-11.014 \mathrm{df}=37$ dan $\mathrm{p}$-value $=0.00<0.05$ yang menunjukan bahwa terdapat perbedaan yang signifikan antara sebelum dan setelah diberikan perlakuan model pembelajaran passing futsal. Berdasarkanhasilpenelitian yang dihasilkan dapat disimpulkan bahwa model pembelajaran passing futsal berbasis 
permainan untuk SMA yang dikembangkan memiliki tingkat efektifitas yang signifikan.

Setelah produk atau model ini dievaluasi mengenai beberapa kelemahan yang ada dan dilakukan pembenahan produk atau model untuk hasil yang lebih baik, maka dapat disampaikan beberapa keunggulan dari produk atau model ini antara lain : (a) dapat meningkatkan kemampuan passing siswa; (b) Model yang dihasilkan memiliki beberapa variasi dari yang termudah hingga tersulit; (c) Model ini akan meningkatkan minat berlatih siswa karena terdapat beberapa variasi pembelajaran, sehingga proses pembelajaran tidak berjalan dengan monoton dan membosankan; (d) Model pembelajaran ini dapat membantu sebagai referensi pelatih untuk menunjang proses pembelajaran passing futsal pada siswa SMA; dan (e) sumbangan bagi ilmu pendidikan khususnya dibidang olahraga futsal.

\section{SIMPULAN}

Dari hasil evaluasi ahli dan uji coba yang telah dilakukan peneliti diperoleh 22 model pembelajaran passing futsal untuk usia SMA yang dapat diterapkan. Berdasarkan validasi ahli dan uji coba, telah dihasilkan suatu produk model pembelajaran passing futsal berbasis permainan untuk siswa SMA yang secara keseluruhan layak untuk digunakan dalam pembelajaran passing futsal. Untuk hasil uji efektifitas model, terbukti secara empiris bahwa hasil produk yang berupa model pembelajaran passing futsal berbasis permainan untuksiswa SMA memiliki efektivitas yang baik dan layak. Hal tersebut didasarkan dari hasil tes passing futsal yang menunjukan bahwa hasil rata-rata posttest dan pretest berbeda signifikan.

\section{DAFTAR PUSTAKA}

Andri, I. 2009. Teknik Dasar Modern Futsal. Jakarta: Pena Pundi Aksara.

Borg, W.R \& Gall, Md. 1983. Educational Research An Introduction. New York: Longman.

Hermans, V., Engler, R. 2011. Futsal-technique, tactics, training. Meyer \& Meyer Sport. 